at present, and require improvement. There are four levels of scientific achievements of students in theprocess of solving problem situations: low, medium, sufficient and high. We submit such components of problem situations as: conditions of a problem situation, a problem, problem solving, criteria for decisions evaluating. The preferences of the problem-based learning are emphasized as opportunities for developing the professionally important qualities of future air traffic controllers, such as: attention, memory, observation, activation of thinking, enhancing cognitive activity, autonomy, responsibility, criticality and self-criticism, initiative, out-of-routine thinking, caution and determination and etc. It is shown that the high quality knowledge management gained and the competent solution of production problems in different activity conditions depends on the usage of problem-type tasks in the professional training of air traffic controllers. Such tasks ensure the formation of students' educational achievements of sufficient and high level, which correspond to the degree of appliance and creativity in future professional activities.

\title{
References
}

1. Bespalko, V.P., 2006. Parametryi i kriterii diagnostichnoy tseli. Shkolnyie tehnologii, 1, s. 118128.

2. Lerner, I.Ya., 1970. Faktoryi slozhnosti poznavatelnyih zadach. Novyie issledovaniya $v$ pedagogicheskih naukah, 1, s.86-92.

3. Makarov, R.N., Gerasimenko, L.V. 1997. Teoriya $i$ praktika konstruirovaniya tselevyih modeley operatorov osobo slozhnyih sistem upravleniya. M.: MAKChAK.

4. Makarov, R.N., Nedelko, S.N., Bamburkin, A.P., Grigoretskiy, V.A. 2005. Aviatsionnaya pedagogika. Kirovograd: MNAPChAK, GLAU.

5. Matyushkin, A.M. 2009. Psihologiya myishleniya. Myishlenie kak razreshenie problemnyih situatsiy. M.: KDU.

УДК 377.091.113-05:[008:005.57

https://doi.org/10.32835/2223-5752.2018.16.61-68.

\section{РОЗВИТОК КОМУНІКАТИВНОЇ КУЛЬТУРИ КЕРІВНИКІВ ЗАКЛАДІВ ПРОФЕСІЙНОЇ ОСВІТИ В СУЧАСНИХ УМОВАХ}

\author{
Олена Пищик, \\ заступник директора з навчально-виробничої роботи \\ ДПТНЗ «Чернігівський иентр професійно-технічної освіти» \\ ORCID: 0000-0001-9193-6645 \\ e-mail:pishik_elena@ukr.net
}

КЛЮЧОВІ СЛОВА:

комунікативна культура, керівники закладів професійної (професійно-технічної) освіти, компетентність, комунікативна компетентність, заклад професійної (професійно-технічної) освіти, управління

\section{Реферат}

У статті розглядаються прикладні аспекти розвитку комунікативної культури сучасних керівників закладів професійної (професійно-технічної) освіти в структурі їх управлінської діяльності. Аналізується зміст комунікативної культури керівників закладів професійної (професійно-технічної) освіти та розуміння феномену комунікативної компетенції як базової складової комунікативної культури керівників закладів професійної (професійно-технічної) освіти. Розглянуто суть поняття «комунікативна культура». Представлено результати дослідження, що проводилося 3 метою вивчення стану комунікативної культури, інтересів, потреб та готовності керівників закладів професійної (професійно-технічної) освіти до розвитку комунікативної культури.

Основна увага у статті приділена діагностиці комунікативної компетенції керівників закладів професійної (професійно-технічної) освіти. Визначено, що процес удосконалення комунікативної компетенції пов'язаний з розвитком особистості. Сучасний керівник закладу освіти повинен володіти не тільки знаннями, навичками та вміннями у своїй галузі, але також мати добре розвинені творчі, комунікативні та інші здібності. Розвиток комунікативної культури керівників закладів професійної (професійно-технічної) освіти має стимулювати керівників-лідерів до отримання психологічних знань, прагнення до самовдосконалення, усвідомлення необхідності розвитку власної комунікативної культури. 
Постановка проблеми. Професійна (професійно-технічна) освіта $є$ складовою системи освіти України. Вона включає комплекс педагогічних та організаційно-управлінських заходів, спрямованих на забезпечення учнів закладів професійної (професійно-технічної) освіти знаннями, уміннями та навичками, на формування загальної і професійної культури.

На шляху розвитку людської цивілізації визначилося розуміння консолідуючої ролі спілкування, значущості комунікативної культури в розвитку людини. Так, наприклад, славетний український філософ Г. Сковорода (1972) вважав, що «життєвий успіх людини залежить не стільки від ऑii різнобічних здібностей та талантів, скільки від ставлення до інших людей, від працьовитості, доброчесності, сумлінності, уміння володіти собою, спілкуватися». Концепція комунікативної культури виникла як логічний розвиток попередніх теоретичних форм рефлексії людського спілкування, проблеми, яка $\epsilon$ постійним супутником соціальної філософської теорії упродовж усієї історії ії існування (Зуєнко, 2009, с.78-79).

Проблема розвитку комунікативної культури не нова, однак потребує більш детального вивчення науковцями та керівникамипрактиками. Тому розвиток високого рівня комунікативної культури як однієї зі складових успішного управління закладом професійної (професійно-технічної) освіти (далі - ЗП(ПТ) O) $€$ актуальним вектором наукових розвідок.

Аналіз наукових праць. Проблеми, пов'язаніз розвиткомосвіти, хвилюють багатьох науковців. Вони значною мірою пов'язані 3 проблемою розвитку комунікативної культури. Про це свідчать вітчизняні дослідження вчених, які розкривають різноманітні аспекти формування та розвитку комунікативної культури в різних сферах діяльності. Зокрема, праці А. Дзундзи, Р. Шулигіної, В. Штифурак, I. Мачуської, Н. Стрельникової присвячені питанням культури спілкування; наукові праці М. Євтуха, С. Поплавської, Т. Черкашиної, Н. Мирончук, Н. Кулик - культурі взаємин; роботи С. Броннікової, О. Кузьмич мовленнєвій культурі тощо. Проблеми формування комунікативної культури фахівців різного профілю розглядали Л. Аухадєєва, Л. Іванченко, I. Зарецька, С. Знаменська, В. Лівенцова, I. Мазаєва, В. Садовська,
С. Сарновська, В. Сморчкова, В. Соколова, Г. Тимченко, О. Шевцова, М. Шовкун, Н. Юрченко та інші.

Плеядою науковців створювалося теоретичне підгрунтя управління освітою, наукові основи, на яких базується діяльність сучасного керівника закладу освіти. Дослідники відзначають глобальну кризу освіти, що супроводжується порушенням гармонії між культурою і ментальністю та призводить до руйнації існуючої парадигми освіти, дестабілізації освітніх систем і, як наслідок, зниження соціальної активності особистості. Все це зумовлює необхідність проведення цілеспрямованої роботи з керівниками ЗП(ПТ) O за напрямом розвитку в них соціальнокомунікативних умінь, що $є$ невід'ємною складовою комунікативної культури. Сучасна ситуація вимагає від керівників ЗП(ПТ)О системи мотивів та цінностей, а також наявність необхідних професійних та особистісних якостей, що забезпечує якість управління закладом професійної освіти.

Мета статі - Розкрити прикладні аспекти розвитку комунікативної культури керівників ЗП(ПТ)О в структурі їхньої управлінської діяльності.

Виклад основного матеріалу. Стратегія розвитку комунікативної культури як основної складової управління ЗП(ПТ)О має базуватися на сучасному законодавчому та нормативному забезпеченні, науково обгрунтованих критеріях оцінювання професійної діяльності керівників ЗП(ПТ)О. Оскільки професійна діяльність керівника-це управління навчальним закладом, то ми розцінюємо переконання Г. Тимошко [2014], що управління - це складний процес, спрямований на забезпечення індивідуального підходу до кожної особистості, який грунтується на суб'єкт-суб'єктній взаємодії керівника і підлеглих, спонукаючи останніх до активності, прояву творчої ініціативи, засвоєння багатогранної культури людства, перетворення зовнішніх норм у внутрішні надбання. Про яку би сферу людської діяльності не йшлося, потрібно зазначити, що утвердження взаємин між людьми залежить від їхньої цілеспрямованої й відповідальної взаємодії, що грунтується на розвинутій комунікативній культурі.

Комунікативна культура є складовою організаційної культури керівника, i ii розуміють по-різному: як частину загальної 
культури особистості; як частину управлінської та професійної культури та як соціально творчу діяльність людей; як сукупність знань, умінь та навичок в області організації взаємодії та розвитку колективу (Куницина та ін., 2001); (Леонтьєв, 2009; Мудрик, 1991).

Комунікативна культура $\epsilon$ однією 3 найбільш важливих професійно значущих характеристик керівників ЗП(ПТ)О, а розвиток комунікативної культури - як першочергове завдання післядипломної педагогічної освіти.

На основі наукових досліджень І. Беха (2008), комунікативну культуру можна розглядати як багатопланове явище становлення i розвитку зв'язків між людьми, що передбачає обмін інформацією, певну тактику і стратегію взаємодії, спрямування і взаєморозуміння між суб'єктами спілкування; регулятор поведінки, гарант шанобливого ставлення особистості до інших, їх розуміння, терплячості та взаємоповаги; один з механізмів гармонізації особистих і громадських інтересів.

Під поняттям «комунікативна культура» ми розглядаємо професійно-комунікативну діяльність колективу учнів та педагогів, спрямовану на реалізацію цілей розвитку закладу освіти, і одночасно, на активізацію людського (кадрового) потенціалу в ньому. Знаходить своє вираження ця культура в системі цінностей і норм поведінки, які складаються під впливом різних факторів у закладі освіти.

На даний процес впливають як зовнішні, так і внутрішні чинники. До зовнішніх можна віднести рівень моральності суспільства, рівень умов праці та якості життя людей, що залежить від реалізації соціальної та кадрової політики держави, від рівня освіти, процесу професіоналізації кадрів тощо.

Внутрішні чинники розвитку комунікативної культури у процесі спілкування відіграють особливо значущу роль у примноженні позитивного іміджу ЗП(ПТ)О. Суб'єктами комунікативної культури $\epsilon$ директор i педагогічний колектив, а об'єктами - учні закладу освіти, але вони також можуть бути по відношенню до самих себе як суб'єкти комунікативної культури. Дуже важливо у процесі комунікації налагоджувати інтерсуб'єктивну (суб'єкт-суб'єктну) взаємодію, засновану на розвиненій комунікативній компетенції, а не суб'єкт- об’єктній, що базується на жорсткій ієрархії управління.

У свою чергу, поняття «комунікативна культура керівників закладів професійної (професійно-технічної) освіти» ми розуміємо як інтегративну властивість особистості, що позиціонується 3 взаємодією учасників освітнього процесу, творчим потенціалом управлінця, його здатністю підтримувати доброзичливе ставлення до оточуючих суб'єктів та проявляється в системі цінностей і норм поведінки, що формуються під упливом різних факторів у закладі освіти.

Одним з істотних елементів комунікативної культури $є$ комунікативна компетентність. 3 точки зору системного підходу, комунікативна компетентність у закладі освіти - це система взаємодій суб'єктів комунікативної культури 3 метою побудови ефективних форм комунікацій як на різних рівнях управління (по вертикалі й горизонталі), так і в процесі виконання персоналом своїх посадових обов'язків, а також в широкому колі неформальних зв'язків.

Українські вчені С. Бондар, I. Гушлевська, О. Овчарук, I. Родигіна, I. Черемис порізному тлумачать поняття компетентності. Найбільшого поширення набуло визначення компетентності як «сукупності знань i умінь, необхідних для ефективної професійної діяльності: уміння аналізувати, передбачати наслідки професійної діяльності, використовувати інформацію» (Ничкало ред., 2000).

Комунікативна компетентність, на думку Е. Руденського (1997), складається iз таких здібностей: надавати соціальнопсихологічний прогноз комунікативній ситуації, в якій має відбуватися спілкуватися; соціально-психологічно програмувати процес спілкування, грунтуючись на своєрідності комунікативної ситуації; здійснювати соціально-психологічне управління процесами спілкування в комунікативній ситуації.

В основу комунікативної компетентності керівників ЗП(ПТ)О покладений процес ефективної комунікації, адже керівник відповідальна особа в процесі налагодження позитивних комунікацій у колективі. На рис. 1 представлена піраміда формування комунікативної компетентності в керівників ЗП(ПТ)O. 


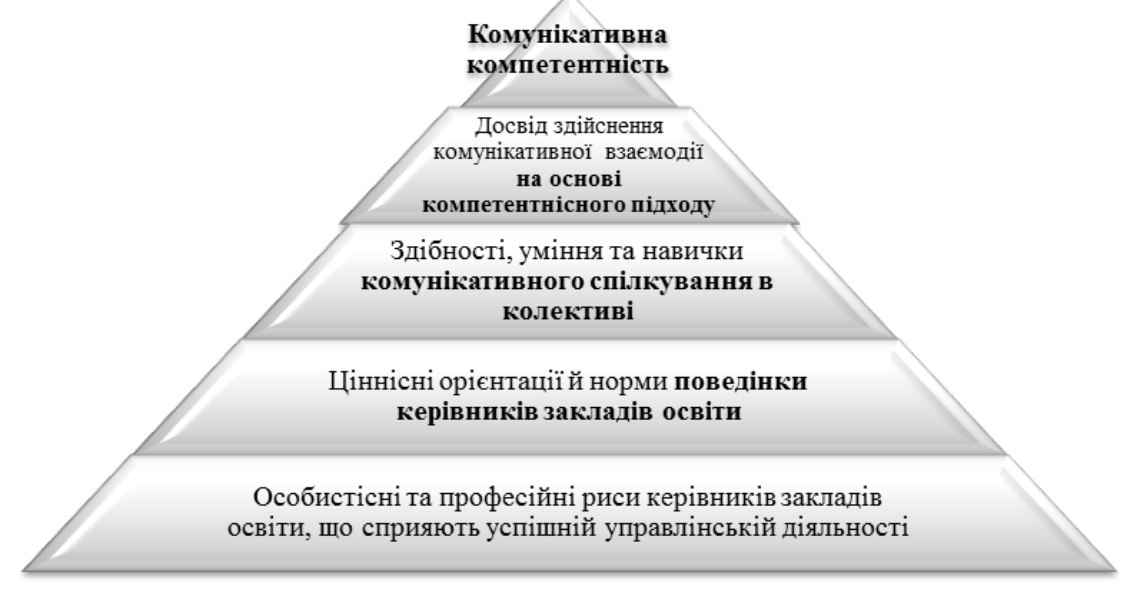

Рис. 1. Структура комунікативної компетентності керівників ЗП(ПТ)О

Керівнику ЗП(ПТ)О важливо мати певний особистісно-професійний потенціал, який дає йому змогу в процесі управлінської діяльності оволодіти високим рівнем комунікативної культури. Сам процес активізації комунікативного потенціалу в особистіснопрофесійну структуру передбачає розвиток цілого комплексу вмінь і навичок, таких, як: уміння виявляти ініціативу в спілкуванні та вибудовувати емоційний контакт 3 учасником спілкування; уміння управляти своїм емоційним настроєм; уміння і навики розуміти стан іншої людини; уміння вибудовувати свій позитивний імідж в особі співрозмовника; вміння вчасно переключити розмову на погоджувальне спілкування тощо.

Важливою складовою розвитку комунікативної культури керівників ЗП(ПТ)О є культура мови.

Культура мови - це дотримання усталених мовних норм усної і писемної літературної мови, а також свідоме, цілеспрямоване, майстерне використання мовно-виражальних засобів залежно від мети й обставин спілкування (Русанівський та ін., 2000).

Мова керівників повинна мати всі властивості погоджувального спілкування та забезпечувати в ЗП(ПТ)О: продуктивне спілкування; позитивно впливати на педагогів, учнів та персонал; створювати систему стимулів та мотивів у професійній поведінціпедагогічнихпрацівників; раціонально вибудовувати організацію їхньої трудової діяльності; створювати позитивний образ ЗП(ПТ)О; підвищувати освітній рівень педагогічного колективу. При цьому мова керівників ЗП(ПТ)О повинна бути: змістовною, точною, логічною, грамотною, 3 точки зору лексики та граматики, позитивно-емоційною, досить гучною та неквапливою. А також мати хорошу дикцію, дотримуватися правил мовного етикету, вміло використовувати невербальні засоби спілкування.

Своєю промовою, стилем спілкування керівництво задає тон комунікативної поведінки в колективі. Під комунікативною поведінкою в ЗП(ПТ)О розуміється проиес професійного спілкування - передачі, приймання та обробки інформації, організації мовлення, створення емоційно-привабливого фону спілкування. Весь цей процес відбивається на стилі, організації та результативності роботи всього персоналу. Комунікативна поведінка грунтується на системі традицій та норм поведінки, характерних для закладу освіти. Для того, щоб комунікативна діяльність будувалася напринципах системності, цілісності, оперативності, необхідно долати комунікативні бар'єри в процесі реалізації професійної діяльності.

Розглянемо на прикладі ЗП(ПТ)О, які бар'єри справді перешкоджають ефективності й результативності в роботі, не сприяють створенню високої комунікативної культури в закладі освіти.

У рамках нашого дослідження щодо розвитку комунікативної культури керівників ЗП(ПТ)О у системі післядипломної педагогічної освіти проводилося опитування 3 проблем функціонування органів влади i

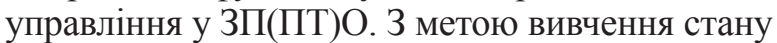
комунікативної культури, інтересів, потреб та 
готовності керівників ЗП(ПТ)О до розвитку комунікативної культури, виявлення іiі складу було проведено дослідження на базі ЗП(ПТ)О в Чернігівській області. В експерименті взяли участь 204 респонденти, а саме: педагоги, батьки й учні ЗП(ПТ)О області. Дані наводяться у відсотках від числа осіб, які надали відповідь на кожне запропоноване питання.

Дослідження показало, що стримуючим бар'єром на шляху розвитку комунікативної культури керівників ЗП(ПТ)О є рівень їхньої комунікативної компетентності (табл. 1).

Таблиця 1

\section{Оцінка рівня комунікативної компетентності керівників ЗП(ПТ)О}

\begin{tabular}{|c|l|}
\hline \multicolumn{2}{|c|}{ Як би Ви оцінили рівень комунікативної компетентності у керівників } \\
\multicolumn{1}{|c|}{ ЗП (ПТ)О } \\
\hline $5,2 \%$ & високий \\
\hline $30,7 \%$ & скоріше високий, ніж низький \\
\hline $38,7 \%$ & скоріше низький, ніж високий \\
\hline $11,5 \%$ & низький \\
\hline $13,9 \%$ & не змогли відповісти \\
\hline
\end{tabular}

Яксвідчатьданітаблиці 1,38,7\%респондентів відзначили, що в керівників навчальних закладів «скоріше низький, ніж високий» рівень комунікативної компетентності, а 11,5\% - стверджують, що він просто низький. Саме низький рівень комунікативної компетентності $\epsilon$ основним проблемним чинником в управлінській діяльності керівників закладів освіти. Відтак, він створює труднощі як у реалізації професійної діяльності керівника, так і в налагодженні дієвих комунікацій.

Керівникам закладів освіти не вистачає i високих особистісних та моральних якостей для того, щоб позиціонувати високий рівень організаційної культури, в тому числі й комунікативної (табл. 2).

Таблиця 2

\section{Оцінка рівня значущості особистісних якостей керівників ЗП(ПТ)О}

\begin{tabular}{|c|c|c|c|c|}
\hline \multicolumn{5}{|c|}{$\begin{array}{c}\text { Якою мірою, на Вашу думку, керівникам ЗП(ПТ)О притаманні такі якості? (відповіді дано по } \\
\text { кожній із визначених якостей) }\end{array}$} \\
\hline № & \multirow{2}{*}{ Якості } & \multicolumn{3}{|c|}{ Ступінь вираженості, \% } \\
\hline & & Низька & Середня & Висока \\
\hline 3 & Доброзичливість & 28,3 & 57,4 & 14,3 \\
\hline 2 & Законослухняність & 22,0 & 55,3 & 22,7 \\
\hline 3 & Відповідальність & 28,6 & 50,3 & 21,1 \\
\hline 4 & Справедливість & 39,8 & 46,3 & 13,9 \\
\hline 5 & Безкорисливість & 44,3 & 42,7 & 13,0 \\
\hline 6 & Чесність & 34,7 & 51,2 & 14,1 \\
\hline 7 & Принциповість & 27,8 & 47,0 & 25,2 \\
\hline 8 & Патріотизм & 41,2 & 45,2 & 13,6 \\
\hline
\end{tabular}

У табл. 2 відображена значущість особистісних рис керівника закладу освіти, які впливають на формування їхньої комунікативної культури. Особливо важливими $є$ такі якості, як: «безкорисливість», «справедливість», «чесність», «патріотизм», які активно впливають на розвиток комунікативної культури керівника.

У процесі нашого дослідження ми переконалися, що керівників ЗП(ПТ)О необхідно готувати до управлінської діяльності, що має відповідати певним критеріям (рис. 2). 


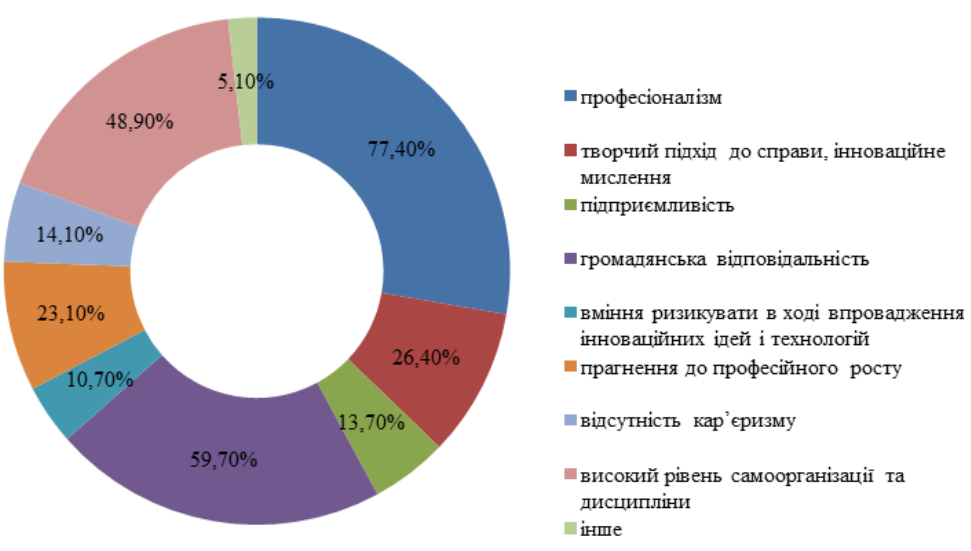

Рис. 2 Критерії добору кандидатів на керівні посади в ЗП(ПТ)О

Данні опитування респондентів, представлені на рис. 2, свідчать про те, що кандидатів на керівні посади у ЗП(ПТ)О необхідно підбирати, виходячи 3 позицій професіоналізму, відповідальності та високої самоорганізації.

3 метою вивчення реального стану комунікативної культури керівників ЗП(ПТ) $\mathrm{O}$, ми дослідили, яких знань найчастіше не вистачає керівникам для належного розвитку їхніх комунікативних здібностей. В опитуванні брали участь 75 керівників ЗП(ПТ)О (директори та їх заступники, завідувачі філіалів, завідувачі відділень, старші майстри, тобто, ті особи, які працюють на керівних посадах, визначених
Типовими штатними нормативами ЗП(ПТ)О). Вони мають затверджені функціональні обов'язки, що корелюють зі змістом наукової категорії «менеджер освіти».

Менеджер освіти - це особа, яка професійно здійснює функції педагогічного менеджменту на рівні будь-якої педагогічної системи. Менеджер навчально-виховного процесу - це працівники закладу освіти які виступають в професійній ролі суб'єктів системи управління навчально-виховною (педагогічною) діяльністю [Крижко, 2005].

Експертне опитування, проведене серед керівників ЗП(ПТ)О, виявило, що в закладах освіти не вистачає фахівців з менеджменту (табл. 3).

\section{Перелік знань з основ наук, необхідних керівникам 3П(ПТ)О}

Таблиця 3

\begin{tabular}{|c|l|}
\hline \multicolumn{1}{|c|}{$\begin{array}{l}\text { Яких знань, на Ваш погляд, не вистачає керівникам ЗाІ(ІТ)О для виконання своїх обов’язків? } \\
\text { (можна було вибрати кілька варіантів відповідей) }\end{array}$} \\
\hline $37,4 \%$ & по теорії та практиці управління \\
\hline $21,5 \%$ & економічних \\
\hline $38,6 \%$ & юридичних \\
\hline $19,5 \%$ & з управління персоналом організації \\
\hline $18,3 \%$ & 3 менеджменту в організації \\
\hline $15,4 \%$ & соціологічних \\
\hline $30,5 \%$ & психологічних \\
\hline $27,6 \%$ & по конфліктології \\
\hline $36,6 \%$ & по мистецтву ділового спілкування \\
\hline $10,6 \%$ & з інформатики \\
\hline $26,8 \%$ & по роботі з використанням інформаційних технологій \\
\hline $4,5 \%$ & інших \\
\hline
\end{tabular}

Яксвідчатьрезультатитабл. 3,керівникиЗП(ПТ) О особливо бажають кращих 3 конфліктології, психології, теорії і практики ділового спілкування. Великий відсоток опитаних серед керівників
ЗП(ПТ)О свідчить про те, що є істотні проблеми в побудові погоджувальних комунікативних зв' язків і відносин. I, як наслідок цих процесів, є потреба в оволодінні мистецтвом ділового спілкування (це 
відзначили 36,6\% керівників 3П(ПТ)О).

У подоланні комунікативних бар'єрів необхідно підвищувати рівень професіоналізму і компетентності керівників ЗП(ПТ)О та одночасно створювати всі умови для залучення на роботу фахівців 3 високим рівнем комунікативної культури. Потрібно зауважити, що в організації управлінської діяльності для створення ефективних комунікацій необхідні: оптимальна організаційна структура; ясні, чіткі і визначені цілі організації; конкретизація цілей кожного рівня управління; чітка регламентація основних видів робіт підрозділів; доступна і ясна система контролю виконання рішень.

Висновки. Розвиток комунікативної культури керівників ЗП(ПТ)О залежить від багатьох факторів, а саме: професіоналізму керівництва та фахівців, рівня їхньої комунікативної компетентності; від системи управління ЗП(ПТ)О; рівня підготовки до управлінської діяльності керівників, яким притаманна належна комунікативна компетентність, високий рівень професіоналізму, відповідні особистісні та професійні якості; усвідомлення критеріїв щодо призначення на керівні посади в ЗП(ПТ)О, уміння вирішувати проблеми організаційні й побутові погоджувальних комунікативних зав'язків та відносин тощо. 3 урахуванням вищезазначеного, стає можливим визначити комунікативну культуру керівників ЗП(ПТ)О як одну 3 умов їхньої ефективної професійної діяльності. Належний розвиток комунікативної культури керівників ЗП(ПТ)О дасть змогу поліпшити організацію управління, підвищити трудову дисципліну, забезпечить злагодженість і чіткість роботи колективу.

\section{Література}

1. Бех, І.Д., 2008. Виховання особистості: підр. Київ: Либідь.

2. Зуснко, Н.О., 2009. Аналіз розвитку поглядів педагогів на комунікативну культуру особистості та його психолого-педагогічні наслідки. Проблеми освіти. Наук.-метод. зб., 59, с.78-79.

3. Крижко, В.В., 2005. Теорія та практика менеджменту в освіті: навч. посібник. Вид. 2-ге допр. К.: Освіта України.

4. Куніцина, В.Н.,Казарінова,Н.В.таПогольша, В. М. 2001. Міжособистісне спілкування. СПб.: Пітер.

5. Леонтьєв, А.А., 2009. Педагогічне спілкування. М.К. Кабардова, ред. 4-е изд., перероб. і доп. М.; Нальчик.

6. Мудрик, А.В., 1991.Соціалізація $i$ «смутні часи»: збірник. М.: Знання. (Нове у житті, науці, техніці; Серія «Педагогіка і психологія»).

7. Дзеверін Д. Г., ред., 1972. Педагогічні ідеї Г.С. Сковороди. К.: Знання.

8. Ничкало, Н.Г., ред., Гончаренко, С.У., уклад. та ін., 2000. Професійна освіта: словник. К.: Вища школа.

9. Руденський, Е.В., 1997. Соціальна психологія. Курс лекиій. М.; Новосибірськ: НГАЕіУ, Сибірська угода.

10. Тимошко, Г.М., 2014. Організащиійна культура керівника загальноосвітнього навчального закладу: теорія та практика: монографія. Ніжин: Видавець ПП Лисенко М.М.

11. Русанівський, В.М. та ін. редкол., 2000. Украйнська мова. Енциклопедія. К.: «Укр.енцикл.».

\section{KEY WORDS:}

culture of communication, heads of vocational schools, competence, communicative competence, vocational education school, management

\section{Abstract \\ Development of communication culture of vocational schools managers Pishchik Elena \\ Deputy Director for training and production work Chernihiv Center of Vocational Education.}

The article deals with the applied aspects of the development of the culture of communication of modern managers of vocational education schools in the structure of their management activities. The research shows the content of the culture of communication of the vocational schools managers and the understanding of the phenomenon of communicative competence as the basic component of the culture of communication of the heads of vocational education schools. The essence of the notion «culture of communication» was considered. The results of the research aimed at studying the state of culture of communication, interests, needs and readiness of the heads of vocational schools to the development of 
culture of communication are presented.

The main attention in the article is paid to the diagnostics of the communicative competence of the heads of vocational and technical education schools. It was determined that the process of improvement of communicative competence is connected with the development of personality. The current head of vocational school in his field should own not only knowledge, skills and abilities, but also well-developed creative, communicative and other abilities. The development of culture of communication of the heads of vocational schools should encourage leaders to obtain psychological knowledge, a desire for self-improvement, and an awareness of the necessity to develop their own culture of communication.

\section{References}

1. Bekh, I.D., 2008. Vykhovannia osobystosti: pidr. M.K. Kabardova, red. 4-e yzd., pererob. i dop. M.; Kyiv: Lybid.

2. Zuienko, N.O., 2009. Analiz rozvytku pohliadiv pedahohiv na komunikatyvnu kulturu osobystosti ta yoho psykholoho-pedahohichni naslidky. Problemy osvity. Nauk.-metod. zb., 59, s.78-79.

Nalchyk.

6. Mudryk, A.V., 1991.Sotsializatsiia $i$ «smutni chasy»: zbirnyk. M.: Znannia. (Nove u zhytti, nautsi, tekhnitsi; Seriia «Pedahohika i psykholohiia»).

3. Kryzhko, V.V., 2005. Teoriia ta praktyka menedzhmentu v osviti: navch. posibnyk. Vyd. 2-he dopr. K.: Osvita Ukrainy.

4. Kunitsyna, V.N., Kazarinova, N.V. ta Poholsha, V.M. 2001. Mizhosobystisne spilkuvannia. SPb.: Piter.

7. Dzeverin D.H., red., 1972. Pedahohichni idei H.S.

Skovorody. K.: Znannia.

8. Nychkalo, N.H., red., Honcharenko, S.U., uklad. ta in., 2000. Profesiina osvita: slovnyk. K.: Vyshcha shkola.

9. Rudenskyi, E.V., 1997. Sotsialna psykholohiia. Kurs lektsii. M.; Novosybirsk: NHAEiU, Sybirska 5. Leontiev, A.A., 2009. Pedahohichne spilkuvannia. uhoda.

УДК 17.023.36-027.561:37:159.9

https://doi.org/10.32835/2223-5752.2018.16.68-73.

\section{ПРОБЛЕМА ФОРМУВАННЯ ПРОФЕСІЙНО-ЕТИЧНОЇ КУЛЬТУРИ У ПСИХОЛОГО-ПЕДАГОГІЧНІЙ ЛІТЕРАТУРІ}

\section{Поліна Прохорчук,}

аспірант, молодший науковий співробітник

лабораторії науково-методичного супроводу в колежах $і$ технікумах

Інституту професійно-технічної освіти НАПН Украӥни

ORCID:0000-0003-2987-5962

e-mail:pella039@gmail.com

\section{КЛЮЧОВІ СЛОВА:}

педагогічні умови, професійно-етична культура, професійна кар'єра, саморозвиток, мотивація

\section{Реферат}

Володіння нормами загальної та професійної культури представлені в статті як важливі якості сучасного фахівця, необхідні для успішного розвитку його особистісної та професійної кар'єри. Обгрунтовано необхідність розвитку цих якостей у процесі професійної підготовки майбутніх графічних дизайнерів, як фахівців, професійна діяльність яких пов'язана 3 образотворчою діяльністю, покликаних створювати візуальні художні образи та оперувати ними. Здійснено аналіз сутності понять «професійна культура» та «педагогічні умови». Зазначено, що в сучасній науково-педагогічній літературі існують різні визначення названих понять. Показано різні погляди сучасних дослідників на обㅍунування сутності поняття «педагогічні умови формування професійно-етичної культури». 3'ясовано, що цей педагогічний феномен пояснюється здебільшого як: сукупність дій, спрямованих на поетапне моделювання й ефективне функціонування процесу становлення й розвитку належного рівня професійно-етичної культури; процес становлення особистості в результаті об'єктивного впливу спадковості, середовища, виховання, самовиховання й педагогічного управління індивідуальним становленням людської особистості. У результаті наукового аналізу психолого-педагогічної літератури виявлено й охарактеризовано основні педагогічні умови, що забезпечують процес формування професійної, етичної, моральної та професійно-етичної культури. Узагальнення поглядів учених дало змогу зробити висновок про те, що найбільш оптимальними для організації професійної підготовки майбутніх графічних дизайнерів можуть бути: вдосконалення знань про механізми творчого саморозвитку, використання інноваційних технологій для формування професійних умінь і навичок, формування позитивної мотивації до професійного успіху. 